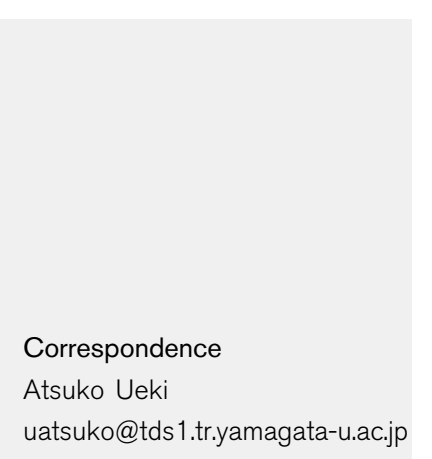

\section{Desulfopila aestuarii gen. nov., sp. nov., a Gram- negative, rod-like, sulfate-reducing bacterium isolated from an estuarine sediment in Japan}

\author{
Daisuke Suzuki, Atsuko Ueki, Aya Amaishit and Katsuji Ueki \\ Faculty of Agriculture, Yamagata University, Wakaba-machi 1-23, Tsuruoka, Yamagata \\ 997-8555, Japan
}

\begin{abstract}
A strictly anaerobic, mesophilic, sulfate-reducing bacterial strain $\left(M S L 86^{\top}\right)$ isolated from an estuarine sediment in the Sea of Japan (around the Japanese islands) was characterized phenotypically and phylogenetically. The cells were found to be Gram-negative, motile, non-spore-forming rods. Catalase was not detected. The optimum $\mathrm{NaCl}$ concentration for growth was $1.0 \%(\mathrm{w} / \mathrm{v})$ and the optimum temperature was $35^{\circ} \mathrm{C}$. Strain $\mathrm{MSL} 86^{\top}$ was slightly alkaliphilic, with optimum growth at $\mathrm{pH}$ 7.5-7.6. Organic electron donors were incompletely oxidized to (mainly) acetate. Strain MSL86 ${ }^{\top}$ utilized formate, pyruvate, lactate, fumarate, ethanol, propanol, butanol and glycerol as electron donors for sulfate reduction and did not use acetate, propionate, butyrate, succinate, malate, methanol, glycine, alanine, serine, aspartate, glutamate or $\mathrm{H}_{2}$. Sulfite, thiosulfate and fumarate were used as electron acceptors with lactate as an electron donor. Without electron acceptors, the strain fermented pyruvate and fumarate. The genomic DNA G $+\mathrm{C}$ content was $54.4 \mathrm{~mol} \%$. Menaquinone $\mathrm{MK}-8\left(\mathrm{H}_{4}\right)$ was the major respiratory quinone. The major cellular fatty acids were $C_{16: 0}, C_{16: 1} \omega 7, C_{16: 1} \omega 5$ and $C_{17: 1} \omega 6$. A phylogenetic analysis based on the $16 \mathrm{~S}$ rRNA gene sequence placed the strain in the class Deltaproteobacteria. The recognized bacterium most closely related to strain $\mathrm{MSL} 6^{\top}$ was $[$ Desulfobacterium] catecholicum DSM $3882^{\top}$ (sequence similarity $94.4 \%$ ), and the next most closely related recognized species were Desulfotalea psychrophila (94.2\% sequence similarity with the type strain) and Desulfotalea arctica (93.7\%). As the physiological and chemotaxonomic characteristics of MSL86 ${ }^{\top}$ were distinctly different from those of any related species, a novel genus and species Desulfopila aestuarii gen. nov., sp. nov. are proposed to accommodate the strain. The type strain of Desulfopila

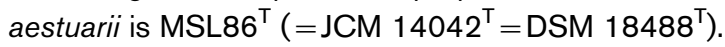

Sulfate-reducing bacteria (SRB) include phylogenetically diverse anaerobic bacterial species (Castro et al., 2000; Kuever et al., 2005). As sulfate levels are sufficient in marine environments, it has been reported that SRBs are responsible for up to $50 \%$ of the organic carbon mineralization in marine sediments (Jørgensen, 1982). Various novel species of SRB have been isolated recently from a wide range of marine sediments (Jeanthon et al., 2002; Sass et al., 2002; Audiffrin et al., 2003; Cravo-Laureau et al., 2004; Moussard et al., 2004; Kuever et al., 2005). In addition, many studies on the diversity of SRB in natural environments have been performed using cultivation-independent molecular

tPresent address: Taisei Corporation, Naze-machi 344-1, Totsuka-ku, Yokohama, Kanagawa 245-0051, Japan.

Abbreviations: CFA, whole-cell fatty acid; SRB, sulfate-reducing bacteria.

The GenBank/EMBL/DDBJ accession number for the $16 \mathrm{~S}$ rRNA gene sequence of strain MSL86 ${ }^{\top}$ is $A B 110542$. techniques based on PCR amplification of the 16S rRNA gene or the dissimilatory sulfite reductase gene (Devereux \& Mundfrom, 1994; Voordouw et al., 1996; Wagner et al., 1998; Joulian et al., 2001; Klein et al., 2001; Purdy et al., 2002; Dhillon et al., 2003; Leloup et al., 2006), and these studies have revealed that phylogenetically diverse lineages of uncultivated SRB are still present in natural ecosystems.

In the course of an investigation on SRB in an estuarine sediment from a Japanese island, we isolated various sulfitereducing strains. The phylogenetic, physiological and chemotaxonomic characteristics of one of the strains, MSL86 $^{\mathrm{T}}$, supported the proposal of a novel genus and species in the class Deltaproteobacteria. Because strain MSL86 $^{\mathrm{T}}$ was isolated from estuarine sediment by the dilution colony-counting method using a sample diluted to $10^{-4}$, it was thought that the SRB group relating to the strain should be present in the sediment at rather high population levels. 
Sediment cores were collected to a depth of $10 \mathrm{~cm}$ using a core sampler (5 $\mathrm{cm}$ in diameter) from sediment at a water depth of $2 \mathrm{~m}$ in the Niida River estuary in Sakata harbour, Japan (i.e. from the Sea of Japan around the Japanese islands; $38^{\circ} 54.5^{\prime} \mathrm{N} 139^{\circ} 50.6^{\prime} \mathrm{E}$ ), on 12 November 2000. The sediment sample was subjected to consecutive 10-fold dilutions with seawater bubbled with $\mathrm{O}_{2}$-free $\mathrm{N}_{2}$ gas. The diluted samples $(0.2 \mathrm{ml})$ were inoculated into seawater agar medium $(10 \mathrm{ml})$ containing $20 \mathrm{mM}$ sodium lactate, and viable colony counts for SRB were determined by using the anaerobic roll-tube method (Hungate, 1966). Several strains of SRB were obtained by picking up black colonies of SRB that appeared on the roll-tube agar after incubation for about a month. Strain MSL86 ${ }^{\mathrm{T}}$ was finally obtained after several purification procedures through colony isolation by the anaerobic roll-tube method.

Two basal media (seawater medium and defined medium) were used in this study. The seawater medium contained the following ( $1^{-1}$ seawater): $0.5 \mathrm{~g} \mathrm{KH}_{2} \mathrm{PO}_{4}, 0.3 \mathrm{~g} \mathrm{NH}_{4} \mathrm{Cl}, 0.1 \mathrm{~g}$ yeast extract, $1 \mathrm{mg}$ sodium resazurin, $10 \mathrm{ml}$ trace element solution $\left(\mathrm{l}^{-1}: 10 \mathrm{ml} 25 \%(\mathrm{v} / \mathrm{v}) \mathrm{HCl}, 1.5 \mathrm{~g} \mathrm{FeCl}_{2} \cdot 4 \mathrm{H}_{2} \mathrm{O}\right.$, $0.19 \mathrm{~g} \mathrm{CoCl}_{2} .6 \mathrm{H}_{2} \mathrm{O}, 0.1 \mathrm{~g} \mathrm{MnCl}_{2} .4 \mathrm{H}_{2} \mathrm{O}, 0.07 \mathrm{~g} \mathrm{ZnCl}_{2}$, $0.062 \mathrm{~g} \quad \mathrm{H}_{3} \mathrm{BO}_{3}, \quad 0.036 \mathrm{~g} \quad \mathrm{Na}_{2} \mathrm{MoO}_{4} \cdot 2 \mathrm{H}_{2} \mathrm{O}, \quad 0.024 \mathrm{~g}$ $\mathrm{NiCl}_{2} \cdot 6 \mathrm{H}_{2} \mathrm{O}$ and $0.017 \mathrm{~g} \mathrm{CuCl}_{2} \cdot 2 \mathrm{H}_{2} \mathrm{O}$ ) and $0.5 \mathrm{~g} \mathrm{~L}$-cysteine hydrochloride monohydrate, as well as an appropriate electron donor. The $\mathrm{pH}$ was adjusted to 7.2-7.4 with $1 \mathrm{M}$ $\mathrm{NaOH}$. Agar (Difco) (1.5\%, w/v) was added to the medium and used for the anaerobic roll-tube method for isolation and in slant cultures (with lactate as an electron donor). A medium designated as the 'defined medium' (distinguishing it from seawater medium) was used for general physiological characterization of the strain, and contained the following $\left(\mathrm{l}^{-1}\right): 0.5 \mathrm{~g} \mathrm{KH}_{2} \mathrm{PO}_{4}, 1.0 \mathrm{~g} \mathrm{NH}_{4} \mathrm{Cl}, 1.0 \mathrm{~g} \mathrm{Na}_{2} \mathrm{SO}_{4}, 2.0 \mathrm{~g}$ $\mathrm{MgSO}_{4} .7 \mathrm{H}_{2} \mathrm{O}, 0.1 \mathrm{~g} \mathrm{CaCl}_{2} .2 \mathrm{H}_{2} \mathrm{O}, 0.5$ g yeast extract, $1 \mathrm{mg}$ sodium resazurin, $10 \mathrm{ml}$ trace element solution, $15 \mathrm{~g} \mathrm{NaCl}$ and $0.5 \mathrm{~g}$ L-cysteine hydrochloride monohydrate (Nakamoto et al., 1996; Ueki et al., 1980; Widdel \& Bak, 1992). The $\mathrm{pH}$ was adjusted to 7.2-7.4 with $1 \mathrm{M} \mathrm{NaOH}$. Cultivation and transfer of the strain were performed under an $\mathrm{O}_{2}$-free $\mathrm{N}_{2}$ $(100 \%)$ atmosphere. The strain was cultivated at $30^{\circ} \mathrm{C}$, unless indicated otherwise. The strain was maintained in slant cultures of the seawater medium or the defined medium with lactate as an electron donor. The $\mathrm{pH}$ of both media after autoclaving was around $\mathrm{pH}$ 6.3. Each electron donor was added at a final concentration of $20 \mathrm{mM}$.

The Gram reaction and cellular morphology were confirmed by light microscopy. The motility of the cells was examined by phase-contrast microscopy, and flagella staining was carried out according to Blenden \& Goldberg (1965). Growth of the strain under aerobic conditions was examined in the presence of sodium lactate as an electron donor, using the defined medium without L-cysteine and sodium resazurin. The catalase and oxidase activities of the cells were tested as described by Akasaka et al. (2003a). The effects of $\mathrm{NaCl}$ concentration and $\mathrm{pH}$ on growth of the strain were examined in the presence of sodium lactate as an electron donor, using the defined medium. The effects of temperature on growth were examined using the seawater medium, with sodium lactate as an electron donor. Growth of the strain was monitored by measuring the $\mathrm{OD}_{660}$ with a spectrophotometer (U-1000; Hitachi).

The utilization of electron donors by strain $\mathrm{MSL} 6^{\mathrm{T}}$ was determined by using the defined medium containing each compound at a final concentration of $20 \mathrm{mM} . \mathrm{H}_{2}$ utilization was determined in the presence of acetate $(5 \mathrm{mM})$ and with $\mathrm{H}_{2}$ in the atmosphere. Utilization of electron acceptors was determined with a sulfate-free medium that contained chloride at the same concentration as that of sulfate in the defined medium; sodium lactate $(20 \mathrm{mM})$ served as an electron donor. Sodium sulfite $(3 \mathrm{mM})$, sodium thiosulfate $(15 \mathrm{mM})$ or disodium fumarate $(20 \mathrm{mM})$ was added to the sulfate-free medium as a possible electron acceptor. The utilization of pyruvate, lactate, fumarate or malate $(20 \mathrm{mM}$ each) in the absence of electron acceptors in the medium was also determined by using the sulfate-free medium. Fatty acids and amino acids were used in the form of sodium salts and added to the medium from sterilized stock solutions. Utilization of each electron donor or acceptor was determined by comparing growth in the presence and absence of each compound, as well as by measuring the concentration in the medium after cultivation.

Volatile fatty acids and alcohols were analysed by GC (G5000 or 263-30; Hitachi), as described by Ueki et al. (1986). Non-volatile fatty acids and formate were analysed by HPLC (LC-10AD; Shimadzu), as described by Akasaka et al. (2003a). Sulfate, sulfite and thiosulfate were analysed with an ion chromatograph (Dionex 2000i), as described by Nakamoto et al. (1996). Genomic DNA was extracted according to the method described by Kamagata \& Mikami (1991). Extracted DNA was digested with P1 nuclease by using a YAMASA GC kit (Yamasa shoyu) and its $G+C$ content was measured by HPLC with Hitachi L-7400 apparatus equipped with a $\mu$ Bondpack C18 column $(3.9 \times 300 \mathrm{~mm}$; Waters $)$. Isoprenoid quinones were extracted as described by Komagata \& Suzuki (1987) and analysed by using a mass spectrometer (JMS-SX102A; JEOL). Whole-cell fatty acids (CFAs) were converted to methyl esters by saponification, methylation and extraction according to the method of Miller (1982). Methyl esters of the CFAs were analysed with a gas chromatograph (Hewlett Packard Hp6890 or Hitachi G-3000) equipped with an HP Ultra2 column. CFAs were identified by means of equivalent chain-lengths (Miyagawa et al., 1979; Ueki \& Suto, 1979) according to the protocol of TechnoSuruga, based on the MIDI Microbial Identification System (Microbial ID) of Moore et al. (1994).

The 16S rRNA gene of strain MSL86 ${ }^{\mathrm{T}}$ was extracted according to the method described by Akasaka et al. (2003a, b) and amplified by PCR using a primer set comprising $27 \mathrm{f}$ and $1492 \mathrm{r}$. The PCR-amplified $16 \mathrm{~S}$ rRNA gene was sequenced by using a Thermo Sequenase primer cycle sequencing kit (Amersham Biosciences) and a DNA 
sequencer (model 4000L; Li-COR). Multiple alignments of the sequence with reference sequences in GenBank were performed with the BLAST program (Altschul et al., 1997). A phylogenetic tree was constructed with the neighbour-joining method (Saitou \& Nei, 1987) by using the CLUSTAL W program (Thompson et al., 1994) as well as the maximum-likelihood program (DNAML) of the PHYLIP 3.66 package (Felsenstein, 2006). All gaps and unidentified base positions in the alignments were excluded before assembly.

The cells of strain MSL86 ${ }^{\mathrm{T}}$ were Gram-negative rods, $0.7-1.2 \mu \mathrm{m}$ wide and 1.9-3.8 $\mu \mathrm{m}$ long with rounded ends; they usually occurred singly or in pairs (Fig. 1). The cells were motile by means of single polar flagella. The strain produced thin, greyish colonies on agar slants of the defined medium as well as the seawater medium. Cells of strain MSL86 $^{\mathrm{T}}$ aggregated during growth in the liquid medium and were deposited at the bottom of the test tubes. Spore formation was not observed.

Strain MSL86 ${ }^{\mathrm{T}}$ reduced sulfate, with lactate as an electron donor, and produced acetate at a molar ratio of about $2: 1: 2$ (lactate/sulfate/acetate) in the defined medium. Thus, the strain showed an incomplete type of oxidation of electron donors. Neither catalase activity nor oxidase activity was detected. The strain could not grow in air in the defined liquid medium. The strain grew in the presence of $\mathrm{NaCl}$ at concentrations up to $5.0 \%(\mathrm{w} / \mathrm{v})$, and the optimum $\mathrm{NaCl}$ concentration for growth was $1.0 \%(\mathrm{w} / \mathrm{v})$. The strain grew in the defined medium even in the absence of added $\mathrm{NaCl}$. The temperature range for growth was $10-40{ }^{\circ} \mathrm{C}$, with an optimum at $35^{\circ} \mathrm{C}$. The strain was slightly alkaliphilic and had a $\mathrm{pH}$ optimum at 7.5-7.6; the $\mathrm{pH}$ range for growth was 6.3-8.5. It could not grow at an initial $\mathrm{pH}$ of 5.6.

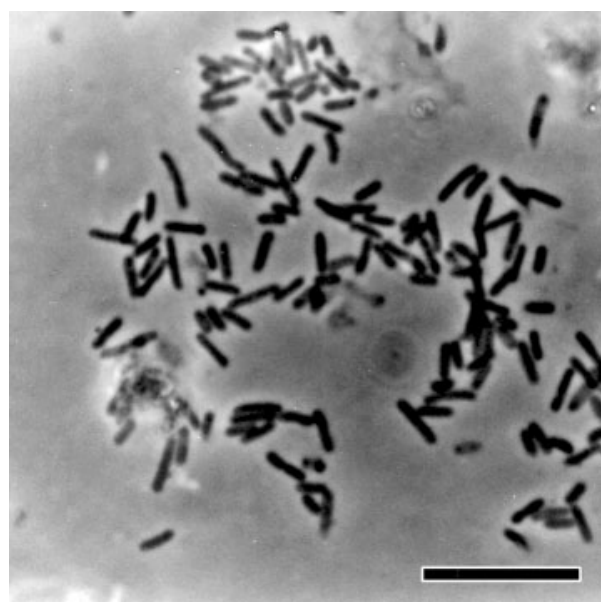

Fig. 1. Phase-contrast photomicrograph of cells of strain MSL86 ${ }^{\top}$ grown anaerobically on an agar slant comprising seawater medium. Bar, $10 \mu \mathrm{m}$.
Strain $\mathrm{MSL}^{\mathrm{T}}{ }^{\mathrm{T}}$ grew even in the absence of added electron donors, and reduced sulfate with the concomitant production of acetate, suggesting that yeast extract or L-cysteine added to the medium was used as an electron donor. The strain utilized formate, pyruvate, fumarate, ethanol, propanol, butanol and glycerol, as well as lactate, as electron donors for sulfate reduction. Although all organic electron donors were usually oxidized to (mainly) acetate, succinate $(2.9 \mathrm{mM})$ was produced in addition to acetate $(8.3 \mathrm{mM})$ when fumarate was used as the electron donor. Propanol and butanol were oxidized to their corresponding carboxylic acids. Strain MSL86 ${ }^{\mathrm{T}}$ did not utilize acetate, propionate, butyrate, malate, succinate, methanol, glycine, alanine, serine, aspartate, glutamate or $\mathrm{H}_{2}$ as electron donors.

Strain MSL86 ${ }^{\mathrm{T}}$ utilized sulfite, thiosulfate and fumarate in addition to sulfate as electron acceptors with lactate as the electron donor. Growth rates in defined medium supplemented with $1.5 \%(\mathrm{w} / \mathrm{v}) \mathrm{NaCl}$ were assessed with fumarate, sulfate, sulfite or thiosulfate as the electron acceptor: the comparison showed that growth was slightly faster with fumarate $\left(\mu=0.096 \mathrm{~h}^{-1}\right)$ than with sulfate $(\mu=$ $\left.0.085 \mathrm{~h}^{-1}\right)$, sulfite $\left(\mu=0.052 \mathrm{~h}^{-1}\right)$ and thiosulfate $(\mu=$ $\left.0.038 \mathrm{~h}^{-1}\right)$. When fumarate was utilized as an electron acceptor, succinate $(3.2 \mathrm{mM})$ and propionate $(1.4 \mathrm{mM})$ were produced in addition to acetate $(7.5 \mathrm{mM})$, in accordance with the oxidation of lactate $(6.7 \mathrm{mM})$. In the absence of electron acceptors, strain MSL86 ${ }^{\mathrm{T}}$ oxidized pyruvate $(10.4 \mathrm{mM})$ and produced acetate $(7.8 \mathrm{mM})$ and propionate $(2.3 \mathrm{mM})$. The strain also oxidized fumarate $(13.0 \mathrm{mM})$ without any electron acceptors, and produced acetate $(9.5 \mathrm{mM})$ and succinate $(7.0 \mathrm{mM})$. The strain did not use lactate or malate in the absence of electron acceptors.

The $\mathrm{G}+\mathrm{C}$ content of the genomic DNA of strain MSL86 ${ }^{\mathrm{T}}$ was $54.4 \pm 0.2 \mathrm{~mol} \%$. The major respiratory quinone was MK- $8\left(\mathrm{H}_{4}\right)$. The predominant CFAs of strain MSL86 ${ }^{\mathrm{T}}$ were $\mathrm{C}_{16: 0}(33.6 \%), \mathrm{C}_{16: 1} \omega 7(6.0 \%), \mathrm{C}_{16: 1} \omega 5(17.1 \%)$ and $\mathrm{C}_{17: 1} \omega 6(13 \cdot 7 \%)$. About $66 \%$ of the total CFAs were evennumbered, straight-chain fatty acids. Smaller amounts of hydroxy fatty acids, iso- $\mathrm{C}_{11: 0} 3-\mathrm{OH}(1.1 \%), \mathrm{C}_{14: 0} 3-\mathrm{OH}$ $(1.8 \%)$ and $\mathrm{C}_{16: 0} 3-\mathrm{OH}(1.6 \%)$, and branched $\mathrm{C}_{17: 1}$ $(4.6 \%)$ were also detected.

On the basis of the almost-complete 16S rRNA gene sequence $(1471 \mathrm{bp})$, strain MSL86 ${ }^{\mathrm{T}}$ is affiliated with the class Deltaproteobacteria. The closest relative (96.3\% sequence similarity) in the public databases was Desulfotalea sp. SFA4, which was isolated from an intertidal flat. The closest known named relative $(94.4 \%$ sequence similarity) of strain MSL86 ${ }^{\mathrm{T}}$ was the SRB [Desulfobacterium] catecholicum DSM $3882^{\mathrm{T}}$ (Szewzyk \& Pfennig, 1987). The next most closely related recognized species were Desulfotalea psychrophila (94.2\% similarity to the type strain) and Desulfotalea arctica (93.7\%) of the Desulfobulbaceae (Kuever et al., 2005). Strain MSL86 ${ }^{\mathrm{T}}$ formed a distinct cluster with strain MSL53, which was isolated from the same sediment as that used to isolate strain MSL86 ${ }^{\mathrm{T}}$ (Fig. 2); the sequence similarity between these two strains was $98.6 \%$. 
It has been proposed that [Desulfobacterium] catecholicum should not remain within the genus Desulfobacterium; $16 \mathrm{~S}$ rRNA gene sequence analysis performed after the original description revealed the need for reclassification of the species as a member of a novel genus within the Desulfobulbaceae (Kuever et al., 2005). The cells of [Desulfobacterium] catecholicum are non-motile and oval to lemonshaped, whereas strain MSL86 ${ }^{\mathrm{T}}$ has motile cells that are typically rod-shaped. Furthermore, [Desulfobacterium] catecholicum belongs to the type of SRB that performs complete oxidation (Szewzyk \& Pfennig, 1987), whereas strain MSL86 $^{\mathrm{T}}$ is of the type that performs incomplete oxidation. As other important physiological characteristics of strain MSL86 $^{\mathrm{T}}$ (including utilization of propionate and butyrate as electron donors for sulfate reduction) also differ from those of [Desulfobacterium] catecholicum (Table 1), strain MSL86 ${ }^{\mathrm{T}}$ should not be affiliated with the novel genus that is needed to accommodate [Desulfobacterium] catecholicum.

Some physiological and chemotaxonomic characteristics of strain MSL86 ${ }^{\mathrm{T}}$ and the two most closely related Desulfotalea species are compared in Table 1. Both of the Desulfotalea species (isolated from permanently cold, Arctic, marine sediments) are psychrophilic SRBs and the optimum growth temperatures of Desulfotalea psychrophila and Desulfotalea arctica are 10 and $18{ }^{\circ} \mathrm{C}$, respectively (Knoblauch et al., 1999), whereas strain MSL86 ${ }^{\mathrm{T}}$ is mesophilic and has an optimum growth temperature of $35^{\circ} \mathrm{C}$. Both of these Desulfotalea species are also SRBs that oxidize incompletely, but the range of electron donors used by strain MSL86 ${ }^{\mathrm{T}}$ differs from those of these species. Strain MSL86 ${ }^{\mathrm{T}}$ utilizes glycerol but not malate, whereas Desulfotalea psychrophila utilizes malate but not glycerol. Strain MSL86 ${ }^{\mathrm{T}}$ utilizes fumarate, propanol and butanol as electron donors, whereas Desulfotalea arctica does not. Strain MSL86 ${ }^{\mathrm{T}}$ does not use amino acids or $\mathrm{H}_{2}$ (with acetate as a carbon source), unlike both of the Desulfotalea species. The range of electron acceptors used by strain MSL86 ${ }^{\mathrm{T}}$ is similar to that of Desulfotalea psychrophila but differs from that of Desulfotalea arctica. Desulfotalea arctica does not utilize sulfite or thiosulfate, whereas strain MSL86 ${ }^{\mathrm{T}}$ utilizes both. In the absence of electron acceptors, strain MSL86 ${ }^{\mathrm{T}}$ and Desulfotalea psychrophila utilize fumarate, unlike Desulfotalea arctica. Strain MSL $86^{\mathrm{T}}$ produced a small amount of propionate, together with acetate, from pyruvate in the absence of electron acceptors. Furthermore, propionate was also produced when fumarate served as an electron acceptor, with lactate as an electron donor. Although some SRBs such as Desulfobulbus and Desulfosarcina species also produce propionate from the fermentation of lactate or pyruvate, these species utilize propionate as an electron donor for sulfate reduction (Kuever et al., 2005). As MSL86 ${ }^{\mathrm{T}}$ does not utilize propionate as an electron donor, propionate production appears to constitute one of the distinctive physiological characteristics of this strain.

The G $+\mathrm{C}$ content of the genomic DNA of strain MSL86 ${ }^{\mathrm{T}}$ $(54.4 \mathrm{~mol} \%)$ is significantly different from those of Desulfotalea psychrophila (46.8 mol\%) and Desulfotalea arctica (41.8 mol\%) (Knoblauch et al., 1999). The respiratory quinones of Desulfotalea species are MK- $6\left(\mathrm{H}_{2}\right)$ or MK-6 (Knoblauch et al., 1999), whereas strain MSL86 ${ }^{\mathrm{T}}$ possesses MK- $8\left(\mathrm{H}_{4}\right)$. Many of the SRBs in the class Deltaproteobacteria (including Desulfovibrio species) contain menaquinone MK-6 or MK-6 $\left(\mathrm{H}_{2}\right)$, and some species in the Desulfobacteraceae possess MK-7 or MK-7 $\left(\mathrm{H}_{2}\right)$ (Kuever et al., 2005). Although it is known that Desulfofaba gelida in the Desulfobacteraceae, a psychrophilic SRB, and sulfurreducing Desulfuromonas species in the Desulfuromonaceae possess MK-8, this is a relatively rare menaquinone in SRBs and related organisms (Kuever et al., 2005). The CFA profiles of strain MSL86 ${ }^{\mathrm{T}}$ and related Desulfotalea species are compared in Table 2. Even-numbered, unsaturated fatty acids $\left(\mathrm{C}_{16: 1} \omega 7\right.$ and $\left.\mathrm{C}_{16: 1} \omega 5\right)$ are the main CFAs found in

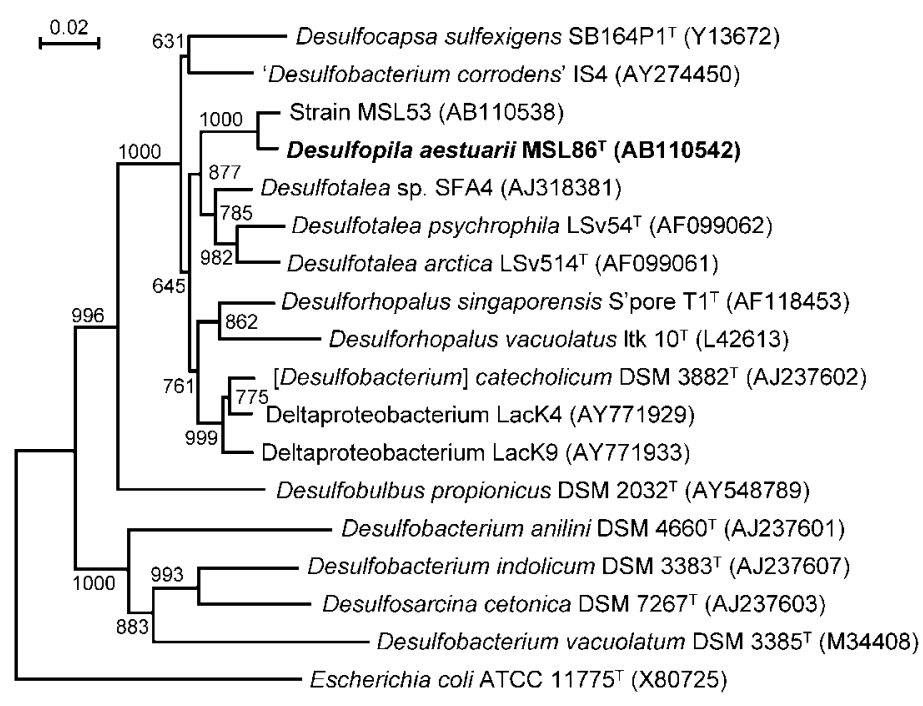

Fig. 2. Neighbour-joining phylogenetic tree, based on 16S rRNA gene sequences, showing the relationships of strain $\mathrm{MSL}^{\top}{ }^{\top}$ and related species in the class Deltaproteobacteria. Bootstrap values shown are based on analysis of 1000 replicates. Escherichia coli ATCC $11775^{\top}$ was used as the outgroup. The tree topology obtained using the maximum-likelihood method was almost the same as that obtained with the neighbour-joining method. Bar, estimated difference of $2 \%$ in nucleotide sequence positions. 
Table 1. Characteristics useful for differentiating strain $M S L 86^{\top}$ from related species

Strains: 1, MSL86 ${ }^{\mathrm{T}}$; 2, Desulfotalea psychrophila LSv54 ${ }^{\mathrm{T}}$ (data from Knoblauch et al., 1999); 3, Desulfotalea arctica LSv514 ${ }^{\mathrm{T}}$ (Knoblauch et al., 1999); 4, [Desulfobacterium] catecholicum NZva20 ${ }^{\mathrm{T}}$ (Szewzyk \& Pfennig, 1987). ND, No data available.

\begin{tabular}{|c|c|c|c|c|}
\hline Characteristic & 1 & 2 & 3 & 4 \\
\hline Isolation source & Estuarine sediment & Arctic marine sediment & Arctic marine sediment & Anoxic mud from a bay \\
\hline Cell shape & Rod & Rod & Rod & Oval to lemon-shaped \\
\hline Motility & + & + & - & - \\
\hline \multicolumn{5}{|l|}{ Optimum growth conditions } \\
\hline $\mathrm{NaCl}(\%, \mathrm{w} / \mathrm{v})$ & 1.0 & 1.0 & $1.9-2.5$ & $0.1^{\star}$ \\
\hline Temperature $\left({ }^{\circ} \mathrm{C}\right)$ & 35 & 10 & 18 & 28 \\
\hline $\mathrm{pH}$ & $7.5-7.6$ & $7.3-7.6$ & $7.2-7.9$ & $6.9-7.1$ \\
\hline \multicolumn{5}{|l|}{ Utilization of electron donors } \\
\hline Acetate & - & - & - & + \\
\hline Propionate & - & - & - & + \\
\hline Butyrate & - & - & - & + \\
\hline Fumarate & + & + & - & + \\
\hline Malate & - & + & - & + \\
\hline Methanol & - & - & - & + \\
\hline Propanol & + & + & - & + \\
\hline Butanol & + & + & - & + \\
\hline Glycerol & + & - & + & ND \\
\hline Glycine & - & + & - & $\mathrm{ND}$ \\
\hline Alanine & - & + & - & ND \\
\hline Serine & - & + & + & $\mathrm{ND}$ \\
\hline Glutamate & - & ND & ND & + \\
\hline $\mathrm{H}_{2}$ & - & + & + & + \\
\hline \multicolumn{5}{|l|}{ Utilization of electron acceptors } \\
\hline Sulfite & + & + & - & + \\
\hline Thiosulfate & + & + & - & + \\
\hline $\begin{array}{l}\text { Fumarate utilization in the } \\
\text { absence of electron acceptor }\end{array}$ & + & + & - & + \\
\hline DNA G + C content $(\mathrm{mol} \%)$ & 54.4 & 46.8 & 41.8 & 52.4 \\
\hline Isoprenoid quinone & $\mathrm{MK}-8\left(\mathrm{H}_{4}\right)$ & MK-6 $\left(\mathrm{H}_{2}\right)$ & MK-6 & ND \\
\hline
\end{tabular}

${ }^{\star}$ Strain $\mathrm{NZva} 20^{\mathrm{T}}$ grows best in freshwater medium containing $0.1 \%(\mathrm{w} / \mathrm{v}) \mathrm{NaCl}$ and does not grow in medium with $\mathrm{NaCl}$ concentrations exceeding $85 \mathrm{mmol}^{-1}$ (approximately $0.5 \%$, w/v).

Desulfotalea species. The high percentages of unsaturated fatty acids (about $90 \%$ ) in CFAs of Desulfotalea species probably represent an adaptation to low temperatures (Knoblauch et al., 1999). Strain MSL86 ${ }^{\mathrm{T}}$ contains much larger amounts of saturated CFAs than do related Desulfotalea species, and the strain contains an oddnumbered, unsaturated fatty acid $\left(\mathrm{C}_{17: 1}\right)$ as one of the main CFAs (this being absent, or present as only a minor CFA, in Desulfotalea species). Thus, strain $\mathrm{MSL} 6^{\mathrm{T}}$ has chemotaxonomic characteristics that are distinct from those of the closely related Desulfotalea species.

On the basis of the phylogenetic, physiological and chemotaxonomic characteristics described above, strain $\mathrm{MSL86}^{\mathrm{T}}$ represents the type species of a novel genus and species in the class Deltaproteobacteria, for which we propose the name Desulfopila aestuarii gen. nov., sp. nov.

\section{Description of Desulfopila gen. nov.}

Desulfopila (De.sul.fo.pi'la. L. pref. de from; L. n. sulfur sulfur; L. fem. n. pila pillar; N.L. fem. n. Desulfopila a sulfatereducing pillar).

Mesophilic. Strictly anaerobic. Cells are Gram-negative, non-spore-forming rods. Sulfate, other inorganic sulfur compounds and fumarate serve as electron acceptors. Organic electron donors are oxidized incompletely to (mainly) acetate. The type species is Desulfopila aestuarii.

\section{Description of Desulfopila aestuarii sp. nov.}

Desulfopila aestuarii (ae.stu.a' ri.i. L. gen. n. aestuarii of an estuary).

Has the following characteristics in addition to those described for the genus. Cells are rod-shaped with rounded 
Table 2. Cellular fatty acid compositions (\%) of strain MSL86 ${ }^{\top}$ and related species

Strains: 1, MSL86 ${ }^{\mathrm{T}}$; 2, Desulfotalea psychrophila LSv54 ${ }^{\mathrm{T}}$ (data from Knoblauch et al., 1999); 3, Desulfotalea arctica LSv514 ${ }^{\mathrm{T}}$ (Knoblauch et al., 1999). -, Not detected.

\begin{tabular}{|c|c|c|c|}
\hline Fatty acid & 1 & 2 & 3 \\
\hline \multicolumn{4}{|c|}{ Saturated straight-chain } \\
\hline $\mathrm{C}_{14: 0}$ & 1.4 & 1.4 & - \\
\hline $\mathrm{C}_{15: 0}$ & - & 0.4 & - \\
\hline $\mathrm{C}_{16: 0}$ & 33.6 & 6.5 & 8.3 \\
\hline $\mathrm{C}_{17: 0}$ & 3.4 & - & - \\
\hline $\mathrm{C}_{18: 0}$ & 2.5 & - & - \\
\hline \multicolumn{4}{|c|}{ Unsaturated straight-chain } \\
\hline $\mathrm{C}_{14: 1} \omega 5$ & - & 1.1 & 1.5 \\
\hline $\mathrm{C}_{15: 1} \omega 6$ & 1.1 & 1.7 & - \\
\hline $\mathrm{C}_{16: 1} \omega 9$ & - & 1.5 & 3.6 \\
\hline $\mathrm{C}_{16: 1} \omega 7$ & 6.0 & 55.0 & 53.9 \\
\hline $\mathrm{C}_{16: 1} \omega 5$ & 17.1 & 25.5 & 29.4 \\
\hline $\mathrm{C}_{17: 1} \omega 6$ & 13.7 & 2.4 & - \\
\hline $\mathrm{C}_{18: 1} \omega 9$ & 1.3 & - & - \\
\hline $\mathrm{C}_{18: 1} \omega 7$ & 1.7 & 1.5 & 1.5 \\
\hline $\mathrm{C}_{18: 1} \omega 5$ & 2.7 & 0.7 & 1.0 \\
\hline \multicolumn{4}{|l|}{ Hydroxy acids } \\
\hline iso- $\mathrm{C}_{11: 0} 3-\mathrm{OH}$ & 1.1 & - & - \\
\hline $\mathrm{C}_{14: 0} 3-\mathrm{OH}$ & 1.8 & - & - \\
\hline $\mathrm{C}_{16: 0} 3-\mathrm{OH}$ & 1.6 & - & - \\
\hline \multicolumn{4}{|c|}{ Unsaturated branched-chain } \\
\hline Branched $\mathrm{C}_{17: 1}$ & 4.6 & - & - \\
\hline
\end{tabular}

ends, $0.7-1.2 \mu \mathrm{m}$ wide and 1.9-3.8 $\mu \mathrm{m}$ long. Motile by a single polar flagellum. Catalase- and oxidase-negative. Colonies are greyish and thin and spread on slant media. The $\mathrm{NaCl}$ concentration range for growth is $0-5.0 \%(\mathrm{w} / \mathrm{v})$, with an optimum at $1.0 \%(\mathrm{w} / \mathrm{v})$. The temperature range for growth is $10-40^{\circ} \mathrm{C}$, with an optimum at $35^{\circ} \mathrm{C}$. Slightly alkaliphilic; the $\mathrm{pH}$ range for growth is $6.3-8.5$, with optimum growth at $\mathrm{pH}$ 7.5-7.6. Utilizes formate, pyruvate, lactate, fumarate, ethanol, propanol, butanol and glycerol as electron donors for sulfate reduction. Does not use acetate, propionate, butyrate, succinate, malate, methanol, glycine, alanine, serine, aspartate, glutamate or $\mathrm{H}_{2}$. Sulfate, sulfite, thiosulfate and fumarate serve as electron acceptors. With fumarate as an electron acceptor and lactate as an electron donor, propionate is produced together with succinate. Pyruvate and fumarate are fermented in the absence of electron acceptors. The genomic DNA G $+\mathrm{C}$ content is $54.4 \mathrm{~mol} \%$. The major CFAs are $\mathrm{C}_{16: 0}, \mathrm{C}_{16: 1} \omega 7$, $\mathrm{C}_{16: 1} \omega 5$ and $\mathrm{C}_{17: 1} \omega 6$. The major respiratory quinone is MK-8 $\left(\mathrm{H}_{4}\right)$.

The type strain, MSL86 ${ }^{\mathrm{T}}\left(=\mathrm{JCM} 14042^{\mathrm{T}}=\right.$ DSM $\left.18488^{\mathrm{T}}\right)$, was isolated from an estuarine sediment located in the Sea of Japan around the Japanese islands.

\section{Acknowledgements}

We are grateful to Drs T. Murayama and K. Takahashi for their technical advice regarding the analysis of isoprenoid quinones. This work was supported by a Grant-in-Aid from the Institute for Fermentation, Osaka.

\section{References}

Akasaka, H., Izawa, T., Ueki, K. \& Ueki, A. (2003a). Phylogeny of numerically abundant culturable anaerobic bacteria associated with degradation of rice plant residue in Japanese paddy field soil. FEMS Microbiol Ecol 43, 149-161.

Akasaka, H., Ueki, A., Hanada, S., Kamagata, Y. \& Ueki, K. (2003b). Propionicimonas paludicola gen. nov., sp. nov., a novel facultatively anaerobic, Gram-positive, propionate-producing bacterium isolated from plant residue in irrigated rice-field soil. Int J Syst Evol Microbiol 53, 1991-1998.

Altschul, S. F., Madden, T. L., Schäffer, A. A., Zhang, J., Zhang, Z., Miller, W. \& Lipman, D. J. (1997). Gapped BLAST and PSI-BLAST: a new generation of protein database search programs. Nucleic Acids Res 25, 3389-3402.

Audiffrin, C., Cayol, J.-L., Joulian, C., Casalot, L., Thomas, P., Garcia, J.-L. \& Ollivier, B. (2003). Desulfonauticus submarinus gen. nov., sp. nov., a novel sulfate-reducing bacterium isolated from a deep-sea hydrothermal vent. Int J Syst Evol Microbiol 53, 1585-1590.

Blenden, D. C. \& Goldberg, H. S. (1965). Silver impregnation stain for Leptospira and flagella. J Bacteriol 89, 899-900.

Castro, H. F., Williams, N. H. \& Ogram, A. (2000). Phylogeny of sulfate-reducing bacteria. FEMS Microbiol Ecol 31, 1-9.

Cravo-Laureau, C., Matheron, R., Cayol, J.-L., Joulian, C. \& Hirschler-Réa, A. (2004). Desulfatibacillum aliphaticivorans gen. nov., sp. nov., an n-alkane- and n-alkene-degrading, sulfate-reducing bacterium. Int J Syst Evol Microbiol 54, 77-83.

Devereux, R. \& Mundfrom, G. W. (1994). A phylogenetic tree of $16 \mathrm{~S}$ rRNA sequences from sulfate-reducing bacteria in a sandy marine sediment. Appl Environ Microbiol 60, 3437-3439.

Dhillon, A., Teske, A., Dillon, J., Stahl, D. A. \& Sogin, M. L. (2003). Molecular characterization of sulfate-reducing bacteria in the Guaymas Basin. Appl Environ Microbiol 69, 2765-2772.

Felsenstein, J. (2006). PHYLIP (phylogeny inference package), version 3.66. Department of Genome Sciences, University of Washington, Seattle, USA.

Hungate, R. E. (1966). The Rumen and its Microbes. New York: Academic Press.

Jeanthon, C., L'Haridon, S., Cueff, V., Banta, A., Reysenbach, A.-L. \& Prieur, D. (2002). Thermodesulfobacterium hydrogeniphilum sp. nov., a thermophilic, chemolithoautotrophic, sulfate-reducing bacterium isolated from a deep-sea hydrothermal vent at Guaymas Basin, and emendation of the genus Thermodesulfobacterium. Int J Syst Evol Microbiol 52, 765-772.

Jørgensen, B. B. (1982). Mineralization of organic matter in the sea bed - the role of sulphate reduction. Nature 296, 643-645.

Joulian, C., Ramsing, N. B. \& Ingvorsen, K. (2001). Congruent phylogenies of most common small-subunit rRNA and dissimilatory sulfite reductase gene sequences retrieved from estuarine sediments. Appl Environ Microbiol 67, 3314-3318.

Kamagata, Y. \& Mikami, E. (1991). Isolation and characterization of a novel thermophilic Methanosaeta strain. Int J Syst Bacteriol 41, 191-196.

Klein, M., Friedrich, M., Roger, A. J., Hugenholtz, P., Fishbain, S., Abicht, H., Blackall, L. L., Stahl, D. A. \& Wagner, M. (2001). Multiple 
lateral transfers of dissimilatory sulfite reductase genes between major lineages of sulfate-reducing prokaryotes. J Bacteriol 183, $6028-6035$.

Knoblauch, C., Sahm, K. \& Jørgensen, B. B. (1999). Psychrophilic sulfate-reducing bacteria isolated from permanently cold Arctic marine sediments, description of Desulfofrigus oceanense gen. nov., sp. nov., Desulfofrigus fragile sp. nov., Desulfofaba gelida gen. nov., sp. nov., Desulfotalea psychrophila gen. nov., sp. nov. and Desulfotalea arctica sp. nov. Int J Syst Bacteriol 49, 1631-1643.

Komagata, K. \& Suzuki, K. (1987). Lipid and cell wall analysis in bacterial systematics. Methods Microbiol 19, 161-207.

Kuever, J., Rainey, F. A. \& Widdel, F. (2005). Class IV. Deltaproteobacteria class nov. In Bergey's Manual of Systematic Bacteriology, 2nd edn, vol. 2, part C, p. 922. Edited by D. J. Brenner, N. R. Krieg, J. T. Staley \& G. M. Garrity. New York: Springer.

Leloup, J., Quillet, L., Berthe, T. \& Petit, F. (2006). Diversity of the $d s r A B$ (dissimilatory sulfite reductase) gene sequences retrieved from two contrasting mudflats of the Seine estuary, France. FEMS Microbiol Ecol 55, 230-238.

Miller, L. T. (1982). Single derivatization method for routine analysis of bacterial whole-cell fatty acid methyl esters, including hydroxy acids. J Clin Microbiol 16, 584-586.

Miyagawa, E., Azuma, R. \& Suto, E. (1979). Cellular fatty acid composition in Gram-negative obligately anaerobic rods. J Gen Appl Microbiol 25, 41-51.

Moore, L. V. H., Bourne, D. M. \& Moore, W. E. C. (1994). Comparative distribution and taxonomic value of cellular fatty acids in thirty-three genera of anaerobic gram-negative bacilli. Int J Syst Bacteriol 44, 338-347.

Moussard, H., L'Haridon, S., Tindall, B. J., Banta, A., Schumann, P., Stackebrandt, E., Reysenbach, A.-L. \& Jeanthon, C. (2004). Thermodesulfatator indicus gen. nov., sp. nov., a novel thermophilic chemolithoautotrophic sulfate-reducing bacterium isolated from the Central Indian Ridge. Int J Syst Evol Microbiol 54, 227-233.

Nakamoto, M., Ueki, A. \& Ueki, K. (1996). Physiological properties of a sulfate-reducing bacterium isolated from municipal sewage sludge and its possible role as a syntrophic acidogen in the ecosystem. J Gen Appl Microbiol 42, 109-120.
Purdy, K. J., Embley, T. M. \& Nedwell, D. B. (2002). The distribution and activity of sulphate reducing bacteria in estuarine and coastal marine sediments. Antonie van Leeuwenhoek 81, 181-187.

Saitou, N. \& Nei, M. (1987). The neighbor-joining method: a new method for reconstructing phylogenetic trees. Mol Biol Evol 4, 406-425.

Sass, A., Rütters, H., Cypionka, H. \& Sass, H. (2002). Desulfobulbus mediterraneus sp. nov., a sulfate-reducing bacterium growing on mono- and disaccharides. Arch Microbiol 177, 468-474.

Szewzyk, R. \& Pfennig, N. (1987). Complete oxidation of catechol by the strictly anaerobic sulfate-reducing Desulfobacterium catecholicum sp. nov. Arch Microbiol 147, 163-168.

Thompson, J. D., Higgins, D. G. \& Gibson, T. J. (1994). CLUSTAL W: improving the sensitivity of progressive multiple sequence alignment through sequence weighting, position-specific gap penalties and weight matrix choice. Nucleic Acids Res 22, 4673-4680.

Ueki, A. \& Suto, T. (1979). Cellular fatty acid composition of sulfatereducing bacteria. J Gen Appl Microbiol 25, 185-196.

Ueki, A., Minato, H., Azuma, R. \& Suto, T. (1980). Enumeration and isolation of anaerobic bacteria in sewage digester fluids: enumeration of sulfate-reducers by the anaerobic roll tube method. J Gen Appl Microbiol 26, 25-35.

Ueki, A., Matsuda, K. \& Ohtsuki, C. (1986). Sulfate reduction in the anaerobic digestion of animal waste. J Gen Appl Microbiol 32, 111-123.

Voordouw, G., Armstrong, S. M., Reimer, M. F., Fouts, B., Telang, A. J., Shen, Y. \& Gevertz, D. (1996). Characterization of 16S rRNA genes from oil field microbial communities indicates the presence of a variety of sulfate-reducing, fermentative, and sulfide-oxidizing bacteria. Appl Environ Microbiol 62, 1623-1629.

Wagner, M., Roger, A. J., Flax, J. L., Brusseau, G. A. \& Stahl, D. A. (1998). Phylogeny of dissimilatory sulfite reductases supports an early origin of sulfate respiration. J Bacteriol 180, 2975-2982.

Widdel, F. \& Bak, F. (1992). Gram-negative mesophilic sulfatereducing bacteria. In The Prokaryotes, 2nd edn, pp. 3352-3378. Edited by A. Balows, H. G. Trüper, M. Dworkin, W. Harder \& K. H. Schleifer. New York: Springer. 